Słota Diana, Wasilewski Tadeusz Pawel, Goniewicz Mariusz, Długoborska Klaudia. The quality of life of patients with nephrolithiasis after the endourological removal of calculi from the urinary tract. Journal of Education, Health and Sport. 2019;9(2):135-144. eISNN 2391-8306. DOI http://dx.doi.org/10.5281/zenodo.2560002

http://ojs.ukw.edu.pl/index.php/johs/article/view/6570

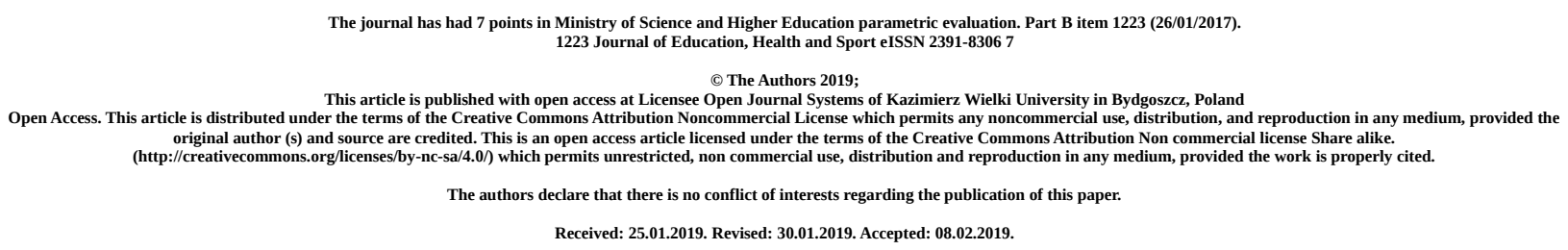

\title{
The quality of life of patients with nephrolithiasis after the endourological removal of calculi from the urinary tract
}

Name

Diana Słota

ORCID iD

http://orcid.org/0000-0002-5681-1684

Affiliation

Medical University of Lublin, Department of Anaesthesiological and Intensive Care Nursing

Country

Poland

Principal contact for editorial correspondence.

Name

Tadeusz Paweł Wasilewski

ORCID iD

http://orcid.org/0000-0003-4686-0500

URL

https://orcid.org/0000-0003-4686-0500

Affiliation

University of Economics and Innovation, Faculty of Human Sciences, Lublin

Country

Poland

Name

Mariusz Goniewicz

ORCID iD

http://orcid.org/0000-0002-3004-6195

Affiliation

Medical University of Lublin, Emergency Medicine Unit

Country

Poland

Name

Affiliation

Klaudia Długoborska

Affiliation

Medical University of Lublin, Department of Anaesthesiological and Intensive Care Nursing

Country

Poland 


\begin{abstract}
Introduction. Nephrolithiasis consists of the production and retention of calculi in the urinary tract. It is being diagnosed in an increasing number of people of any age, and is one of the most common ailments in the world. Depending on a number of factors, it can be found in $5-20 \%$ of the population. Traditional surgeries are being replaced by less invasive methods of treatment. The relation between the endourological removal of calculi from the urinary tract and the assessment of the quality of life of patients who have undergone such procedures is an interesting topic worth analysing. In the 21 st century, quality of life became the indicator of the efficacy of many therapies and procedures. It is associated with the quality of treatment, reflecting a better and longer life with the disease.
\end{abstract}

Objective. The objective of this study is to demonstrate the quality of life of the surveyed patients with nephrolithiasis after the endourological removal of calculi from the urinary tract.

Materials and methods. The group of surveyed individuals qualified for statistical analysis included 120 people diagnosed with nephrolithiasis. The patients underwent the procedure of the endourological removal of calculi from the urinary tract in 2015 in three hospitals in eastern Poland. Among the respondents, $48 \%$ of them underwent extracorporeal shock wave lithotripsy (ESWL), $31 \%$ had percutaneous nephrolithotripsy (PCNL), and 21\% had uretherorenoscopic lithotripsy (URS). To evaluate the quality of life, a research tool was devised based on an abbreviated version of the Polish adaptation of the WHOQOL - BREF questionnaire. Also, a personal questionnaire prepared by the author was used.

Results and conclusions. The analysis of the collected materials demonstrated the impact of the endourological removal of calculi from the urinary tract on the quality of life of the hospitalised patients. Differences were identified in individuals' general rating of quality of life $(57 \%$ of respondents were satisfied) and patients' general satisfaction with their health $(47.5 \%$ of respondents were satisfied) after the procedure. Significant differences were identified in each of the studied fields: physical, psychological, social and environmental. A statistically significant correlation of $\mathrm{p}<0.05$ was observed between the respondents' rating of their quality of life in individual fields, and their gender and age, place of residence, education and type of procedure.

Key words: nephrolithiasis, quality of life (QoL), WHOQOL - BREF, endourological removal of calculi 


\section{Introduction}

Renal stone disease (urolithiasis, nephrolithiasis) is a disease of the urinary tract consisting in the production and storage of deposits (stones) in urinary tracts [1].

The formation of kidney stones is a complex process and may be genetically determined. The presence of urolithiasis is positively correlated with a high-protein diet and body weight $>30$ body mass index (BMI) [2].

Urolithiasis occurs in an increasing number of people of all ages. It is one of the most common diseases in the world.

Depending on the geographical region, sex, age and race of patients, about $5-20 \%$ of the population is affected. It is estimated that renal calculosis accounts for about $1 \%$ of all hospitalizations. It can be considered as a systemic and civilization disease, creating more and more economic, therapeutic and social problems $[3,4]$.

Kidney stones are a serious risk factor for chronic kidney disease, high blood pressure $[5,6,7,8]$ and ischemic myocardial disease $[9,10]$.

Therefore, the conclusion is that preventing the development and recurrence of kidney stones should be one of the key elements of prevention of cardiovascular disease.

The treatment of urolithiasis over the last three decades has undergone a revolutionary transformation. The introduction of minimally invasive methods into urological instruments has made classical open surgery a rare occurrence and is usually carried out with the co-existence of other urinary tract pathologies requiring surgical treatment. The location of the deposit and its size are crucial in the selection of the treatment method $[2,7,8]$.

The most common methods of removing urinary tract deposits are endourological procedures such as ESWL (extracorporeal shock wave lithotripsy), PCNL (percutaneous nephrolithotomy) and URS (ureterorenoscopy, uretherorenoscopic lithotripsy). They are less invasive than traditional surgical procedures and usually do not require longer hospitalization. In connection with the above, the patient undergoing endourological treatment is less stressed and heals faster $[2,4,6,11]$.

Quality of life in the twenty-first century has become the determinant of the effectiveness of many therapies and treatments. It is related to the quality of treatment, giving an image of a better and longer life in the disease. Many factors influence the quality of life, which translate into 
physical, mental and intellectual abilities. They depend both on the family situation, job satisfaction and financial condition $[12,13]$.

According to the WHO (World Health Organization), the quality of life depends on the state of health, or the person's sense of mental, physical and social status.

\section{Objective}

The objective of this study is to demonstrate the quality of life of the surveyed patients with nephrolithiasis after the endourological removal of calculi from the urinary tract.

\section{Materials and methods}

The research was conducted from June to September 2015 at the Provincial Hospital John Paul II in Zamość, The 1st Military Hospital in Lublin and the Specialist Public Health Care Center in Szczebrzeszyn. Patients participating in the study were informed about the purpose of the study and gave their written consent for their participation. In addition, the consent of the Bioethics Commission was obtained for the needs of the research.

The group of study patients qualified for the study was 120 people (ie 100\%), including 65 men (ie 65\%) and 55 women (ie 55\%). In order to conduct own research, a research tool was used based on a short version of the WHOQOL-BREF questionnaire in the Polish translation of Wołowicka and Jaracz [13], used to assess the quality of life of healthy and sick people. The personal questionnaire was also used.

Adapting own questionnaire for own research made it possible to obtain a quality of life profile of patients after endourological procedures to remove urinary deposits in the scope of four spheres of life. These were the spheres of physical, psychological, social functioning and functioning of patients in its environment. Each scale consists of subscales, which show more details of individual spheres [12,13].

The scope of physical functioning included 7 questions covering the assessment of everyday activities, dependence on medication and treatment, vital energy and fatigue, mobility, pain and discomfort, rest and sleep, and ability to work. The scope of psychological functioning contained 6 questions covering the assessment of external appearance, negative and positive feelings, selfesteem, spirituality, religion, faith and thinking, learning, memory, concentration. The scope of social functioning included 3 questions that concerned the assessment of personal relationships, social support and sexual activity. The scope of the patient's functioning in his environment included 6 questions covering the assessment of financial resources, freedom and physical and 
mental safety, opinions on health and medical care, home environment, acquiring new skills and information, participation in rest and recreation, the external environment.

In addition to the above-mentioned spheres of quality of life, the questionnaire contained two questions that were analyzed separately. They concerned individual, general perception of quality of life and individual, general perception of one's own health $[12,13]$.

Obtained results of own research were subjected to statistical analysis. The values of the measurable parameters analyzed were presented using the mean value, median value, minimum and maximum values as well as standard deviation, and for non-measurable using the number and percentage. For qualitative features, in order to justify the relationship between the analyzed variables, the Chi2 test was used. The Mann-Whitney $U$ test was used to show differences in the subjective assessment of the quality of life between the two groups of subjects, and the KruskalWallis test for more than two groups. A significance level of $\mathrm{p}<0.05$ was assumed indicating the existence of statistically significant differences or dependencies. The database and statistical surveys were based on the Statistica 9.1 computer software (StatSoft, Poland).

The spheres of physical, mental and environmental functioning were positive, i.e. the higher the score was obtained, this indicated a better assessment of the quality of life. However, the sphere of social functioning had a negative direction, which means that the higher the number of points obtained, the worse the quality of life.

The analysis of each question was made on the basis of a point scale ranging from 1 to 100 . The following signs were assumed in the presented work: $\mathrm{n}$ - number of people, $\mathrm{m}$ - average, SD standard deviation, $\mathrm{t}$ - test results for independent samples, $\mathrm{p}$ - significance of the statistical sample.

\section{Results}

The age of the patients examined ranged from 18 to 61 years. The most numerous group were people aged 40 to $61(\mathrm{n}=57$, ie $47.50 \%)$.

The analysis of own research showed that in the area of an individual general assessment of the quality of life 68 , ie $56.67 \%$ of the surveyed patients were satisfied with the quality of their life after the endourological removal of calculi from the urinary tract. Among the examined patients, 42 people, ie $35.00 \%$, indicated an average level of satisfaction with the quality of life, while 10 people, ie $8.33 \%$ expressed dissatisfaction with their quality of life after endourological surgery. 


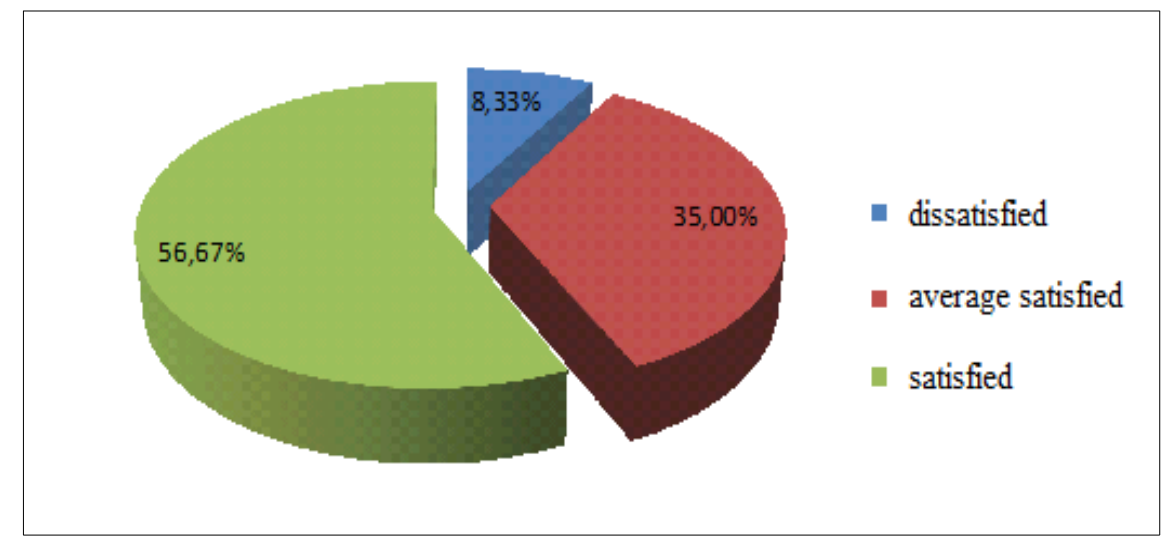

Figure 1. Individual general assessment of the quality of life

Own research showed that, in the area of individual overall health perception, 57 patients, ie $47.50 \%$, were satisfied on average. 55 people were satisfied with their health, ie $45.83 \%$, while 8 patients, ie $6.67 \%$ were dissatisfied with their health condition.

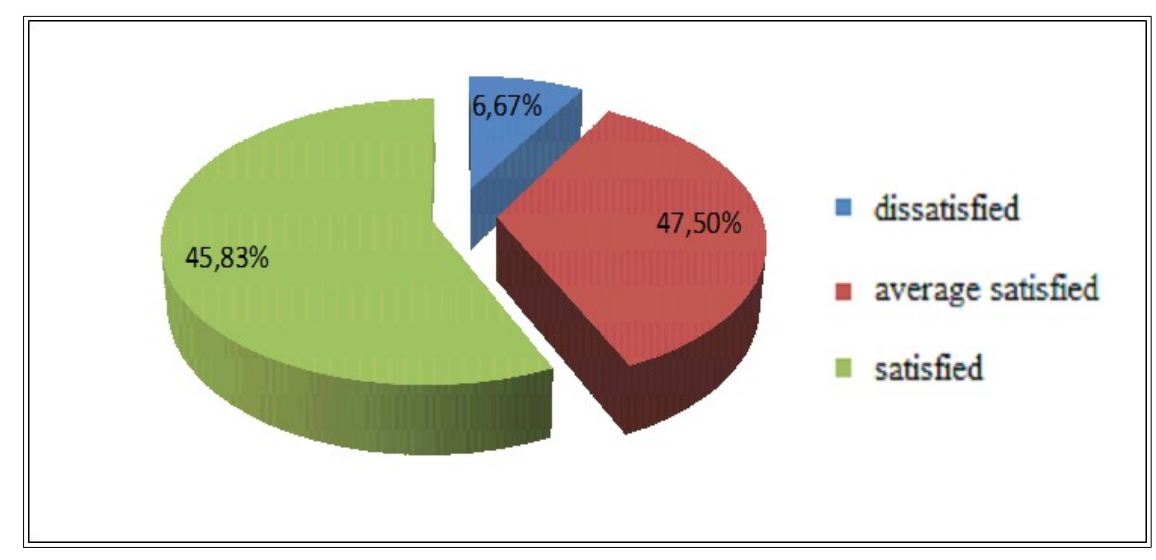

Figure 2. Individual general assessment of one's own health

Material analysis allows the occurrence of a significant statistical relationship between the assessment of the quality of life of the examined patients and their gender. Studies have shown that men were characterized by the highest quality of life in the social sphere, while women rated their quality of life in the somatic and psychological spheres better.

Considering the age of the examined patients, it should be stated that the lowest quality of life in each of the spheres was assessed by people over 61 years of age. 
Table 1. Comparison of the four analyzed areas of quality of life based on the sex of the examined patients

\begin{tabular}{|c|c|c|c|c|c|c|}
\hline \multirow{2}{*}{ Spheres of quality of life } & \multicolumn{2}{|c|}{ Women } & \multicolumn{2}{|c|}{ Men } & \multirow{2}{*}{ Z } & \multirow{2}{*}{$\mathrm{p}$} \\
\hline & $\mathrm{M}$ & SD & $\mathrm{M}$ & SD & & \\
\hline Somatic sphere & 66,45 & 11,99 & 64,75 & 12,86 & 0,265 & 0,791 \\
\hline Psychological sphere & 64,64 & 10,80 & 62,35 & 13,23 & 0,760 & 0,447 \\
\hline Social sphere & 65,11 & 11,75 & 75,09 & 9,59 & $-4,326$ & $<0,001$ \\
\hline Environmental sphere & 72,07 & 10,70 & 72,31 & 9,07 & $-0,019$ & 0,985 \\
\hline
\end{tabular}

The analysis of own research showed that in the examined group of patients only statistically significant differences occurred only in the social sphere. It should be noted that men were more likely to have a higher quality of life in the social sphere than women.

Table 2. Comparison of the four analyzed areas of quality of life due to the age of the examined patients

\begin{tabular}{|c|c|c|c|c|c|c|c|}
\hline \multirow[t]{2}{*}{ Spheres of quality of life } & \multicolumn{2}{|c|}{$\begin{array}{l}\text { Patients up to } \\
40 \text { years of age } \\
\text { (I) }\end{array}$} & \multicolumn{2}{|c|}{$\begin{array}{c}\text { Patients from } 41 \\
\text { to } 60 \text { years } \\
\text { (II) }\end{array}$} & \multicolumn{2}{|c|}{$\begin{array}{l}\text { Patients over } 61 \\
\text { years } \\
\text { (III) }\end{array}$} & \multirow[t]{2}{*}{$\mathrm{P}<0,001$} \\
\hline & M & SD & M & SD & M & SD & \\
\hline Somatic sphere & 68,56 & 15,96 & 68,65 & 10,40 & 58,33 & 9,40 & \multirow{4}{*}{$\begin{array}{l}\text { Differences } \\
\text { between } \\
\text { groups I-II } \\
\text { I-III, II-III }\end{array}$} \\
\hline Psychological sphere & 65,70 & 15,25 & 65,7 & 12,94 & 58,56 & 5,43 & \\
\hline Social sphere & 75,89 & 4,30 & 71 & 10,02 & 65,72 & 15,67 & \\
\hline Environmental sphere & 75,63 & 8,25 & 74,18 & 10,83 & 66,50 & 6,31 & \\
\hline
\end{tabular}


The analysis of own research showed statistically significant differences between the age groups of the examined patients. It turns out that in each of the spheres the lowest quality of life was characterized by patients over 61 years of age.

\section{Discussion}

The analysis of the literature on the subject over the last years emphasizes the need to make a subjective assessment of the quality of life of patients suffering from kidney stones, including patients after endourological surgery to remove urinary tract deposits.

The application of the Quality of Life questionnaire in patients with urolithiasis has been extensively described in the studies by Penninston et al. $[14,15,16,17]$. The questionnaires that were used by the authors are SF-36 and author's, validated, consisting of 28 Wisconsin Stone-QoL test questions (WiSQoL). The above studies show that the lowest quality of life assessments were obtained by patients with renal colic symptoms. However, the publications do not pay attention to the search for connections between such factors as sex and age and the assessment of the quality of life or health of patients after endourological surgery to remove urinary tract deposits.

According to Kupajski et al. [18], the final result of endorologic PCNL and URSL procedures in patients with one kidney is affected by risk factors such as age, gender, BMI or ASA score.

There are also few reports on the influence of abnormal, intestinal bacterial flora destroyed by antibiotics, which is one of the main risk factors for the occurrence of oxalate-calcium stones [19].

Our own research also showed a lower level of quality of life in the somatic, psychological, social and environmental sphere in the patients over 61 years of age. The results of our own research seem to confirm the studies of Bensalah et al. [20] in which the authors assessed the quality of life of patients with urolithiasis. The authors showed that the higher age together with the increased BMI was the strongest determinant of the deteriorated physical well-being. The increase in the number of procedures for endourological removal of stones, however, had an impact on the deteriorated quality of life in the psychological aspect.

Noteworthy are the studies by Makarewicz et al. [21] who wrote about the quality of life of patients after surgical procedures performed using the laparoscopic or classic method. The authors showed that less invasive treatments than classical operations have a positive effect on the quality of life of patients.

In view of the above, it seems that proper selection and unification of methods for measuring post-operative quality of life of patients allows introducing new standards and procedures in 
medical care. It is also important to analyze and assess the quality of life of patients suffering from civilization diseases, including kidney stones.

\section{Conclusions}

Based on the analysis of own research, the following conclusions were determined:

- undertaking endorological procedures for removal of kidney stones improves the quality of life of patients,

- age and gender have an impact on the quality of life of the examined patients,

- patients over 60 years of age have a lower quality of life in the somatic, psychological, social and environmental spheres than younger patients,

- men confirm a higher level of quality of life in the social sphere than surveyed women.

\section{References}

1. Duława J.: Czynniki rozwoju kamicy nerkowej. Forum Nefrologiczne. 2009; 2(3):184-188

2. Matych J.: Sikorska-Radek P., Jałmużna P.: Kamica nerkowa - postępowanie w ostrym epizodzie. Medycyna po dyplomie maj, 2014: 64-68

3. Curhan G.C.: Epidemiology of stone disease. Urol Clin North Am 2007; 34: 2238 - 2243

4. Myśliwiec M., Brzóska Sz.: Kamica moczowa. [w]: Myśliwiec M. (red.) Choroby nerek. Wydawnictwo Lekarskie PZWL, Warszawa, 2008: 371-380

5. Taylor E.N., Stampfer M.J., Curhan G.C.: Obesity, weight gain and the risk of kidney stones. JAMA 2005; 293: 455-462

6. Cappuccio F.P., Kalaitzidis R., Duneclift S., Eastwood J.B.: Unravelling the links between calcium excretion, salt intake, hypertension, kidney stones and bone metabolism. J Nephrol 2000; 13: 169-177 7. Matuszewski M.: Kamica moczowa - wytyczne European Association of Urology. Przegląd urologiczny 2016/4: 37-42

8. Mutrynowski T., Torz C., Dzigowski P., Radziszewski P., Borkowski A.: Kamica układu moczowego. Medycyna po Dyplomie 2011(20), 8(185): 91-94

9. Eisner B.H., Cooperberg M.R., Curhan G.C.: Nephrolithiasis and the risk of cardiovascular disease. J. Urol. 2007; 177: 44-49

10. Hamano S., Nakatsu H., Suzuki N.: Kidney stone disease and risk factors for coronary heart disease. Int J Urol. 2005;12: 859-863

11. Różański W., Markowski M., Blewniewski M.: Nowe możliwości PCNL. Przegląd Urologiczny 2015; 1: 89: 40-44 
12. Papuć E.: Jakość życia - definicje i sposoby jej ujmowania. Curr Probl Psychiatry 2011; 12 (2): 141-145

13. Wołowicka L, Jaracz K.: Jakość życia w naukach medycznych. Wydawnictwo Uczelniane Akademii Medycznej w Poznaniu, Poznań, 2001

14. Penniston K.L., Nakada S.Y.: Health related quality of life differs between male and female stone formers. J Urol 2007; 178: 24-35

15. Penniston K.L., Nakada S.Y.: Development of an instrument to assess the health related quality of life of kidney stone formers. J Urol. 2013;189(3): 921-930

16. Penniston K.L., Davis V.P., et al.: The Wisconsin stone quality of life questionnaire: baseline results from a prospective, longitudinal, multi-center validation study. J Urol. 2015; 193(4): 304-305.

17. Penniston K.L., et al.: Validation and Reliability of the Wisconsin Stone Quality of Life Questionnaire. J Urol 2017; 197(5): 1280-1288

18. Kupajski M, Tkocz M, Ziaja D.: Ocena czynników ryzyka mogących wpłynąć na ostateczny wynik zabiegów PCNL i URSL u chorych z nerką jedyną z uwzględnieniem wieku chorych, ich płci, wielkości BMI oraz skali ASA. Chirurgia Polska 2015; 17(1-2): 1-6

19. Spadlo A, Kowalewska-Pietrzak M, Młynarski W.: Probiotyki w zapobieganiu i leczeniu hiperoksalurii i kamicy szczawianowo-wapniowej. Przeglad Pediatryczny 2008; 38(3): 218- 221

20. Bensalah K., Tuncel A., Gupta A., Raman J.D., Pearle M.S., Lotan Y.: Determinants of Quality of Life for Patients With Kidney Stones. The Journal of Urology 2008; 179, 6: 22-43

21. Makarewicz W., Kaska Ł., Stefaniak T., Kobiela J., Śledziński Z.: Operacje wideoskopowe w zakresie chirurgii gastroenterologicznej i endokrynologicznej. Wideochirurgia i inne techniki małoinwazyjne. 2006; 2: 87-93 